\title{
Impact of Agricultural Trade Policies on the Exportation of Agricultural Commodities in Nigeria
}

\author{
Udoh, Brian Christopher ${ }^{*} \quad$ Adelaja, Olusumbo Adeolu \\ Institute of Agribusiness Management Nigeria (IAMN), \\ Beside Atanda High School, Oluyole Estate, Ibadan, Oyo State, Nigeria
}

\begin{abstract}
This study focused on the impact of agricultural trade policies on the exportation of agricultural commodities in Nigeria. A total of three hundred and seventy (370) certified exporters of agricultural commodities (cocoa, cashew and ginger) were simple randomly selected for this study. Data was analyzed using descriptive statistics and regression analysis. Results showed that the major agricultural trade policy actions that positively impacted export commodity productivity and supply volume were Ancho Borrowers Programme (2.848), Duty free imports of agricultural equipment (2.632) and Nigeria Incentive-Based Risk Sharing System for Agricultural Lending (2.572). Constraints faced by the exporters include high transportation costs, unfavorable weather condition, unfavorable government policy, and so on. Moreover, educational level, experience, source of farmland used for cultivation and source of seedlings were significantly related $(p<0.01)$ with period when exporters supplied the highest volume of agricultural commodities. The study recommends that favourable policies to exporters of agricultural commodities should be enacted.
\end{abstract}

Keywords: Impact, trade, policies, agricultural commodities, economy

DOI: $10.7176 / \mathrm{JESD} / 12-16-05$

Publication date:August $31^{\text {st }} 2021$

\section{Introduction}

Due to oil boom in 1970s, attention was shifted to the oil sector while the role of agriculture in the economy of Nigeria was neglected. This led to the decline of exportation and increase in importation of agricultural products in the country (Ayinde et al., 2015). Government only gave minute support to the agricultural sector and based on this, focus was on exporting crops such as groundnut, rubber, cotton, palm kernel and cocoa; which makes the country to be the primary exporter of numerous agricultural products but unfortunately lost her governance place in agricultural products export (Mesike et al., 2007). In the economy of Nigeria, agriculture has been the most significant distinct activity which provides around $70 \%$ of job opportunities to the people. It is the major sector of the Nigerian economy which provides employment opportunities for a vital section of the labor force and constituting the backbone of the rural community of the country which justifies almost two-third of the populace (Ijirshar, 2015). In 2019, National Bureau of Statistics reported that agriculture contributed about $21.91 \%$ to the Gross Domestic Product (GDP) of the country (Plecher, 2020).

Increase of agricultural export has been a huge achievement story which has led to abundant benefits to the country hence, the significance of export to a country's economic development and growth cannot be exaggerated (Verter \& Bečvařova, 2014; Verter, 2015). Likewise, it is a source of foreign exchange earnings because transaction of trade among countries are paid in foreign exchange. Similarly, it brings commodity diversity which increases varieties to the public (Verter \& Bečvařova, 2014). To some level, trade sustains steady demand and supply that permits effective exchanges and encourage economic development and growth among countries (Erokhin et al, 2014; Verter \& Bečvařova, 2014). However, exportation of agricultural produce can hasten an equilibrium development throughout the countries that are engaged in the disputes like trade distortions and restrictions (Laborode \& Martin, 2012; Verter, 2015).

According to CBN, (2010), numerous agricultural programme and policy in the nation go along with food crop produce and variability of price. The knowledge of the sensitivity of export supply to price changes and non-price elements is crucial in formulation of comprehensive broad export policy bundle. In any case export supply reacts undesirably to prices, changes of price cannot lead to rise in export volume (Gbetnkom \& Khan, 2002). Recently, Nigerian agricultural exports have faced reduction in income due to price variability at the international market (Osabuohien et al., 2018). With policies that are conducive, there will be increase in agricultural production and this will also lead to increase in export earnings. Therefore, the general objective of this study is to assess the impact of agricultural trade policies on the exportation of agricultural commodities in Nigeria.

\section{Literature Review}

2.1 Trade Policies in the Agricultural Sector

According to Josling et al. (2010), agricultural trade policies are generally among the subtlest in any international trade discussions. In Nigeria, agricultural policies have faced four main phases from 1960 to 1969 , 
followed by 1970 to 1979 during the period of oil booming, also from 1980 to late 1990s during structural adjustment program (SAP) and lastly during implementation of National Economic Empowerment and Development Strategy (NEEDS) agenda. During the era of SAP agenda in Nigeria, emphasis was mainly on dispersal of export base away from oil sector and emerging non-oil earnings from foreign exchange. In order to realize this, lots of policy reformation and incentives to stimulate the trade of non-oil tradable imports and likewise expansion of export market of Nigeria was created (Daramola, et al., 2007; Ayodele, 2009).

The role of agricultural export is very significant in the economic development in Nigeria by providing the needed foreign exchange revenues for other investment development projects (Ijirshar, 2015). Agricultural sector performance was confronted by other policies that were unfavorable, specifically the introduction of SAP which placed a ban on importation of some food items in order to upsurge the local products yield (Akinbamwo, 2013). Also, the animal production sector (poultry and fishery) growth was adversely affected due to the subsequent outrageous cost of inputs as a result of currency devaluation which was one of SAP features (Akinbamwo, 2013). Furthermore, Love (2020) opine that instruments of trade policy like import tariffs, export duties and quantitative limitations on imports and exports in Nigeria impacts inputs and outputs prices of agricultural commodities.

Theoretically, agricultural policies are supposed to affect various phases of agriculture. Implementation of agricultural policies are intended to accomplish detailed goals like increase in level of production, availability of farm inputs, upsurge in value addition and decrease of food price amidst others (Ayinde et al., 2015). Findings from Ayinde et al. (2015) studies discovered that agricultural policies during structural adjustment period (SAP), post-structural adjustment period (PSAP) and agricultural credit guarantee scheme funds (ACGSF) were statistically important whereas the agricultural input subsidy agenda was statistically irrelevant. As specified by Emerole and Edeoga, (2013); Ekiran et al. (2014), a lot of agricultural programmes and policies have failed in the past such as Operation Feed the Nation (OFN) programme in 1976, Green Revolution Programme (GRP) in 1980, while in 1986 structural adjustment programme (SAP) was introduced alongside with many policy programmes and packages like National Agricultural Land Development Authority (NALDA), Directorate of Food, Roads and Rural Infrastructures (DFRRI) and River Basin Development Authority but failed in the southern zone of the nation while minute success was recorded in the northern part of Nigeria. All these programme are fixed on fiscal policy of the financial stabilization policy with maximum purpose to develop agricultural yield, lessen food import bills, develop foreign exchange via agricultural exportation and boost domestic production (Agricultural Transformation Agenda, 2011). Despite all these enticements to increase exportation of non-oil in the nation, much achievement has not been recorded from export volume as anticipated (Emerole \& Edeoga, 2013). Studies of Verter and Bečvařova, (2016) revealed that a vibration to agricultural exports can lead to variation in the long run to the alteration of economic growth.

However, Emerole and Edeoga, (2013) studies indicated that the export of non-oil agriculture has the potential of contributing to the country's economic growth whereas the hostile foreign exchange nature constituted a foremost challenge. Moreover, Ekiran et al. (2014) studies revealed that appropriate policy combination needs to be put in position by the government in order to network influx of capital toward expansion of agricultural productivity in the process of upsurge of agricultural export to achieve economic development in Nigeria. Furthermore, Emenyonu et al. (2020) studies indicated that there exists a long run association in the model between agricultural export and fiscal policy variables. Similarly, Akanni et al. (2005) stated that policy had great impact on the value and export level of agricultural commodities. Based on literatures reviewed, scholars focused more on agricultural exports and economic growth (Gbaiye et al., 2013; Ijirshar, 2015; Verter \& Bečvařova, 2016).

In 1985, Government of India established Agricultural and Processed Food Products Export Development Authority (APEDA) with the aim of promotion of export and development of products such as vegetables, fruits, dairy products, cocoa and its products, bakery and biscuits, cereals, etc. This gave the exporters the avenue to interact with the authorities concerning the supply chain of agricultural products and challenges encountered. Some of the challenges identified include unregulated farm input usage like chemicals at the farm level, insufficient harvest management influence the quality as well as shelf life of the produce, certification and processes to be followed by exporters, inadequate awareness on prevailing systems as well as policies associated to exports, underdeveloped link roads from the farms to the main road in most of the states, difficulty in connecting land locked production areas to the terminals or ports and high congestion at the ports as a result to high waiting periods of the shipment.

Furthermore, India has a topographical benefit on account of its different as well as favorable climatic conditions for cultivation of vegetables and fruits. There is necessity to accomplish an economical production scale, price competitiveness, construct suitable storage distribution infrastructure as well as technical involvements to have a significant share in the international market. Study conducted by Assem and Sebastian, (2013) in Egypt indicated that institutional environment, limited ability to match quality criteria in foreign markets, inadequate variation of export destinations and then potential economic susceptibility to price, fluctuations of exchange rate or price and failure of growers in Egypt to produce quantities of exportable desired 
quality of commodities were the observed barriers faced by exporters of agricultural commodities in Egypt. Similarly, Okpara and Kumbiadis, (2008) reported that some of the barriers facing export include lack of information on demands of foreign market and lack of full records on export processes and code of practice. Likewise, Irwin and Scott (2010) indicated that incapacity to acquire financial services for transactions of export; fluctuations of exchange rate and high interest rates; and transportation costs all contributed to the challenges of export (Morgan, 1997; Dekle and Heajin, 2007; Briggs, 2007).

Exports play a vital role for financial development because they encourage local production as well as increase foreign exchange supply (Koksal, 2008). Numerous studies (Haahti et al., 2005; Sousa et al., 2008) have concentrated on export obstacles encountered by firms in various sectors as well as countries. Nevertheless, in developing countries, empirical research precisely examining barriers of export confronted by firms are not common (Tesform \& Lutz, 2006; Al-Hazaimeh et al., 2011). Additionally, most of the prior studies concentrated on firms exporting non-agricultural produce with little focus given to exporting organizations of primary agricultural commodities (Kazem \& Heijden, 2006). Hence, the need to conduct empirical studies for enhanced understanding of exportation of agricultural commodities becomes vital. Therefore, this study assessed the impact of agricultural trade policy actions on export commodity productivity and supply volume and constraints faced by exporters of agricultural commodities in Nigeria.

\section{Methodology}

Nigeria is the study area where the study was conducted. The country is positioned between the longitudes $3^{0} \mathrm{E}$ and $15^{\circ} \mathrm{E}$ and latitudes $4^{0} \mathrm{~N}$ and $14^{\circ} \mathrm{N}$; and located in the West Africa. The major source of foreign exchange in the country is agriculture. The objective of this research is to assess the impact of trade policies on the flow of agricultural commodities in Nigeria. Cross sectional data was used for this study in order to get first-hand and adequate information directly from the farmers involved in export of agricultural commodities in Nigeria. The target respondents are farmers that export cashew, cocoa and ginger in Nigeria. From the Cashew Farmers' Association of Nigeria, they have around 50,000 members while roughly 3,000 were active members. Likewise, Ginger Growers, Processors and Marketers Association of Nigeria (GGPMAN) have 200,000 members but about 4,000 were active members. However, Cocoa Farmers Association of Nigeria (CFAN) have over 150,000 registered farmers while around 2500 were active members. It was also revealed that not all active members were involved in exportation. As a result of this, simple random sampling method was used to select one hundred and twenty (120) certified cashew farmers, one hundred and fifty (150) certified ginger farmers and one hundred (100) certified cocoa farmers making a total of 370 respondents which were used for this study. Structured questionnaire was designed in google docs form while the link was sent to the respondents for them to fill and data were gathered through this means. The questionnaire was divided into three parts; demographic factors, trade policies on exportation of agricultural commodities and constraints encountered by exporters. Data collected were analyzed using descriptive statistics, multiple regression and correlation. This study approved the use of mean value in form of a four (4) point Likert scale to determine the extent to which the agricultural trade policies actions have impacted export commodity productivity and supply volume. The response choices and values allotted were as follows: I don't know $=1$, no impact $=2$, negatively $=3$ and positively $=4$. Decision point: $\leq 2.5$ Reject, $>2.5$ Accept. This was in line with Nwabunike (2015) who used five point likert scale.

Decision rule: Mean $(X)=\Sigma \mathrm{X} / \mathrm{n}=4+3+2+1=10 / 4=2.5$

$\Sigma=$ summation

$\mathrm{X}=$ value Likert

$\mathrm{N}=$ number of items

Multiple regression was used to determine the relationship between age of respondents, level of education, export experience, source of agricultural farm land used for cultivation and source of seedlings with the years' exporters supplied the highest volume of agricultural commodities. The model is stated as follows:

$\mathrm{SHV}=\mathrm{f}($ Age, LOE, EE, SOAFL, SS $)$.

$\mathrm{SHV}=\beta_{0}+\beta_{1}$ Age $+\beta_{2} \mathrm{LOE}+\beta_{3} \mathrm{EE}+\beta_{4} \mathrm{SOAFL}+\beta_{4} \mathrm{SS}+£$

Where, $\beta_{0}=$ Constant

$\beta_{1-4}=$ Coefficient of explanatory variables

Age $=$ Age of respondents

LOE $=$ Level of education

$\mathrm{EE}=$ Export experience

SOAFL $=$ Source of agricultural farm land used for cultivation

$\mathrm{SS}=$ Source of seedlings

$\mathrm{SHV}=$ Years exporters supplied the highest volume of agricultural commodities 


\section{Results}

\subsection{Demographic Factors of Respondents}

The descriptive statistics of respondents was presented in Table 1. Result showed that most $(35.1 \%)$ of the respondents were from the South-west region, followed by North-central (25.4\%) and North-west $(23.2 \%)$ and the least is South-east (5.7\%). Most (45.4\%) of the respondents fell within the age group of 30-40 years and about $65 \%$ of the respondents were males. Findings revealed that almost all $(95.4 \%)$ of the respondents had tertiary education while just few (4.6\%) had secondary education respectively. The mean years of exportation experience of farmers was 5.84 years. Half $(50.8 \%)$ of the respondents belonged to exporters association group. Majority (82\%) of the respondents lacked access to credit facilities. Almost $47 \%$ of the respondents stated that they had training on production and export of exportable agricultural commodities while $53.2 \%$ of the respondents indicated that they did not had any form of training.

Table 1: Descriptive statistics of demographic factors of respondents $(n=370)$

\begin{tabular}{lll}
\hline Variables & Frequency & Percentage (\%) \\
\hline Geo-political zone & & \\
North-central & 94 & 25.4 \\
North-east & 39 & 10.5 \\
North-west & 86 & 23.2 \\
South-west & 130 & 35.1 \\
South-east & 21 & 5.7 \\
Age (years) & 34 & \\
18-30 & 168 & 9.2 \\
30-40 & 94 & 45.4 \\
$40-50$ & 74 & 25.4 \\
$50-60$ & $30-40 y e a r s \pm .912$ & 20.0 \\
Mean \pm std. & & \\
Sex & 238 & 64.3 \\
Male & 132 & 35.7 \\
Female & & \\
Level of education & 0 & 0.0 \\
No formal education & 0 & 0.0 \\
Primary education & 17 & 4.6 \\
Secondary education & 353 & 95.4 \\
Tertiary education & & \\
Years of farmers' experience of exportation & 147 & 39.7 \\
1-5 & 200 & 54.1 \\
6-10 & 0 & 0 \\
11-15 & 23 & 6.2 \\
Above 15 & $5.84 \pm 4.379$ & \\
Mean \pm std. & & \\
Member of any exporters association group & 182 & 49.2 \\
Yes & 188 & 50.8 \\
No & & \\
Access to credit facilities & 69 & 18.6 \\
Yes & 301 & 81.4 \\
No & & 46.8 \\
Training on production and export & 173 & 53.2 \\
Yes & 197 & \\
No & & \\
\hline Source: & & \\
\hline
\end{tabular}

Source: Field data survey, 2021

4.2 Impacts of Agricultural Trade Policy actions on Export Commodity Productivity and Supply Volume Table 2 showed the descriptive statistics of impacts of agricultural trade policy actions on export commodity productivity and supply volume. 4-point Likert scale was also used in which the decision rule was 2.5 and any value below it was rejected. Out of the nineteen (19) agricultural trade policies, results revealed that only five (5) had an impact on export commodity productivity and supply volume which include Ancho Borrowers Programme in 2015 (2.848), followed by Unpeging of the Nigerian naira against the Dollar in 2016 (2.800), Duty free imports of agricultural equipment in 2012 (2.632), NIRSAL (Nigeria Incentive-Based Risk Sharing System for Agricultural Lending 2013 and Nigeria provides companies income tax holidays to pioneer status 2014 (2.518). Moreover, the percentage result showed that Duty free imports of agricultural equipment in 2012 
(44.9\%), NIRSAL (Nigeria Incentive-Based Risk Sharing System for Agricultural Lending in 2013 (33\%) and Ancho Borrowers Programme in 2015 (36.5\%) had positive impact on export commodity productivity and supply volume while Nigeria provides companies income tax holidays to pioneer status $2014(28.1 \%)$ and Unpeging of the Nigerian naira against the Dollar in $2016(51.9 \%)$ had negative impact on export commodity productivity and supply volume.

Table 2: Descriptive statistics of impact of agricultural and trade policy actions on export commodity productivity and supply volume

\begin{tabular}{|c|c|c|c|c|c|c|}
\hline Trade policies & $\begin{array}{l}\text { I don't } \\
\text { know } \\
\text { Freq. }(\%)\end{array}$ & $\begin{array}{l}\text { No } \\
\text { impact } \\
\text { Freq. } \\
(\%)\end{array}$ & $\begin{array}{l}\text { Negatively } \\
\text { Freq. (\%) }\end{array}$ & $\begin{array}{l}\text { Freq. } \\
(\%)\end{array}$ & $\begin{array}{l}\text { Mean } \\
\text { value }\end{array}$ & Decision \\
\hline Export Processing Zone 1992 & $168(45.4)$ & $78(21.1)$ & $37(10.0)$ & $87(23.5)$ & 2.116 & Rejected \\
\hline $\begin{array}{l}\text { Trade Liberalization Scheme (TLS) } \\
\text { (ECOWAS) } 2000\end{array}$ & $169(45.7)$ & $77(20.8)$ & $14(3.8)$ & $110(29.7)$ & 2.175 & Rejected \\
\hline Interest Drawback Scheme 2003 & $165(44.6)$ & $78(21.1)$ & $54(14.6)$ & 73(19.7) & 2.094 & Rejected \\
\hline $\begin{array}{l}\text { Nigerian Export Processing Zones } \\
\text { Authority (NEPZA) } 2004\end{array}$ & $112(30.3)$ & $78(21.1)$ & $68(18.4)$ & $112(30.3)$ & 2.486 & Rejected \\
\hline $\begin{array}{l}\text { Manufacturers in bond Schemes } \\
2005\end{array}$ & $117(31.6)$ & $109(29.5)$ & $54(14.6)$ & $90(24.3)$ & 2.316 & Rejected \\
\hline Bank of Agriculture (BOA) 2010 & $115(31.1)$ & $78(21.1)$ & $65(17.6)$ & $112(30.3)$ & 2.470 & Rejected \\
\hline $\begin{array}{l}\text { Commercial Agriculture Credit } \\
\text { Scheme (CACS) } 2010\end{array}$ & $138(37.3)$ & $92(24.9)$ & $37(10.0)$ & $103(27.8)$ & 2.2837 & Rejected \\
\hline $\begin{array}{l}\text { Growth Enhancement Support } \\
\text { Scheme } 2012\end{array}$ & $173(46.8)$ & $92(24.9)$ & $37(10.0)$ & $68(18.4)$ & 2.000 & Rejected \\
\hline $\begin{array}{l}\text { Duty free imports of agricultural } \\
\text { equipment } 2012\end{array}$ & $112(30.3)$ & $78(21.1)$ & $14(3.8)$ & $166(44.9)$ & 2.632 & Accepted \\
\hline $\begin{array}{l}\text { Export Expansion Grant (EEG) } \\
\text { Scheme-suspension } 2013\end{array}$ & $116(31.4)$ & $131(35.4)$ & $31(8.4)$ & $92(24.9)$ & 2.2675 & Rejected \\
\hline $\begin{array}{l}\text { NIRSAL (Nigeria Incentive-Based } \\
\text { Risk Sharing System for } \\
\text { Agricultural Lending } 2013\end{array}$ & $99(26.8)$ & $82(22.2)$ & $67(18.1)$ & $122(33.0)$ & 2.572 & Accepted \\
\hline $\begin{array}{l}\text { Nigeria provides companies income } \\
\text { tax holidays to pioneer status } 2014\end{array}$ & $84(22.7)$ & $96(25.9)$ & 104(28.1) & $26(23.2)$ & 2.518 & Accepted \\
\hline Ancho Borrowers Programme 2015 & $63(17.0)$ & $65(17.6)$ & $107(28.9)$ & $135(36.5)$ & 2.848 & Accepted \\
\hline $\begin{array}{l}\text { CBN export repatrition regime } \\
\text { (Circular) - } 2015\end{array}$ & $119(32.2)$ & $130(35.1)$ & $53(14.3)$ & $68(18.4)$ & 2.1837 & Rejected \\
\hline $\begin{array}{l}\text { Common External Tariff (CET) } \\
2015\end{array}$ & $119(32.2)$ & $114(30.8)$ & $59(15.9)$ & $78(21.1)$ & 2.259 & Rejected \\
\hline $\begin{array}{l}\text { Unpeging of the Nigerian naira } \\
\text { against the Dollar - } 2016\end{array}$ & $84(22.7)$ & $0(0.0)$ & 192(51.9) & $94(25.4)$ & 2.800 & Accepted \\
\hline $\begin{array}{l}\text { Nigeria ratified the WTO Trade } \\
\text { Facilitation Agreement } 2017\end{array}$ & $119(32.2)$ & $57(15.4)$ & $103(27.8)$ & $91(24.6)$ & 2.448 & Rejected \\
\hline Export Development Funds 2018 & $120(32.5)$ & $114(30.8)$ & $51(13.8)$ & $85(23.0)$ & 2.270 & Rejected \\
\hline $\begin{array}{l}\text { NXP Automation } \\
\text { repatriation to non-oil domiciliary } \\
\text { account) } 2019\end{array}$ & $120(32.4)$ & $61(16.5)$ & $95(25.6)$ & $94(25.4)$ & 2.440 & Rejected \\
\hline
\end{tabular}

\section{Source: Field data survey, 2021}

4.3 Constraints Encountered in the Export of Agricultural Commodities (Cocoa, Cashew and Ginger)

Table 3 presented the descriptive statistics of constraints encountered in the export of agricultural commodities (cocoa, cashew and ginger). From the study, results revealed that unfavorable weather conditions (64.3\%), lack of government support and access to credit facilities (57.8\%), high transportation costs (57.0\%), high tariffs $(46.2 \%)$, price fluctuations $(43.0 \%)$ and unfavorable government policy $(35.9 \%)$ were very severe constraints encountered in the export of agricultural commodities. Moreover, poor access to information (53.5\%) was also a severe constraints identified by the exporters. 
Table 3: Descriptive statistics of constraints encountered in the export of agricultural commodities (cocoa, cashew and ginger)

\begin{tabular}{lllll}
\hline Variables & $\begin{array}{l}\text { Very } \\
\text { Severely } \\
\text { Freq. (\%) }\end{array}$ & $\begin{array}{l}\text { Severely } \\
\text { Freq. (\%) }\end{array}$ & $\begin{array}{l}\text { A } \begin{array}{l}\text { little } \\
\text { Freq. (\%) }\end{array} \\
\text { Freq. (\%) }\end{array}$ & $\begin{array}{l}\text { Not at all } \\
\text { Freq. }\end{array}$ \\
\hline $\begin{array}{l}\text { High transportation costs } \\
\text { Lack of government support and access to credit } \\
\text { facilities }\end{array}$ & $\begin{array}{l}211(57.0) \\
214(57.8)\end{array}$ & $\begin{array}{l}112(30.3) \\
131(35.4)\end{array}$ & $\begin{array}{l}22(5.9) \\
0(0.0)\end{array}$ & $25(6.8)$ \\
Unfavorable weather condition & $238(6.8)$ \\
Poor access to information & $45(12.2)$ & $198(53.5)$ & $62(16.8)$ & $65(17.6)$ \\
Unfavorable government policy & $133(35.9)$ & $173(46.8)$ & $39(10.5)$ & $25(6.8)$ \\
Price fluctuations & $159(43.0)$ & $134(36.2)$ & $52(14.1)$ & $25(6.8)$ \\
Change in demand & $52(14.1)$ & $150(40.5)$ & $143(38.6)$ & $25(6.8)$ \\
High tariffs & $171(46.2)$ & $117(31.6)$ & $17(4.6)$ & $65(17.6)$ \\
Non-tariff barriers & $108(29.2)$ & $89(24.1)$ & $108(29.2)$ & $65(17.6)$ \\
Poor export facilitation services & $197(53.2)$ & $131(35.4)$ & $17(4.6)$ & $25(6.8)$ \\
\hline
\end{tabular}

Source: Field data survey, 2021

\subsection{Regression Analysis}

Table 4 showed the anova result from the regression analysis while Table 5 revealed the coefficient results. The anova result showed that the model was statistically significant at $1 \%$ level based on the F statistics value which was 37.930. The value of $\mathrm{R}$ square was 0.343 which showed that $34.3 \%$ of the total variation in the dependent variable was accounted for by the independent variables included in the model.

Table 4: Anova

\begin{tabular}{llllll}
\hline Model & Sum of Squares & df & Mean Square & F & Sig. \\
\hline Regression & 456.626 & 5 & 91.325 & 37.930 & $.000^{*}$ \\
Residual & 876.405 & 364 & 2.408 & & \\
Total & 1333.031 & 369 & & & \\
Adjusted $\mathbf{R}^{\mathbf{2}}$ & .334 & & & & \\
$\mathbf{R}^{\mathbf{2}}$ & .343 & & & & \\
\hline
\end{tabular}

*Significant $\mathrm{p}<0.05$

Findings in Table 5 revealed that level of education (2.474), export experience (-.194), source of farmland used for cultivation (.623) and source of seedlings (.404) were all significant at $1 \%$ level to the period when exporters supplied the highest volume of agricultural commodities.

Table 5: Coefficient table

\begin{tabular}{|c|c|c|c|c|c|}
\hline \multirow[t]{2}{*}{ Model } & \multicolumn{2}{|c|}{$\begin{array}{l}\text { Unstandardized } \\
\text { Coefficients }\end{array}$} & $\begin{array}{l}\text { Standardized } \\
\text { coefficients }\end{array}$ & \multirow[b]{2}{*}{$\mathbf{t}$} & \multirow[b]{2}{*}{ Sig. } \\
\hline & B & Std. Error & Beta & & \\
\hline Constant & 2005.559 & 2.394 & & 837.710 & .000 \\
\hline Age of respondent & -.053 & .114 & -.025 & -.465 & .642 \\
\hline Level of education & 2.474 & .559 & .273 & 4.423 & $.000 * * *$ \\
\hline Export experience & -.194 & .021 & -.447 & -9.142 & $.000 * * *$ \\
\hline $\begin{array}{l}\text { Source of farmland used for } \\
\text { cultivation }\end{array}$ & .623 & .135 & .267 & 4.623 & $.000 * * *$ \\
\hline Source of seedlings & .404 & .092 & .225 & 4.416 & $.000 * * *$ \\
\hline
\end{tabular}

Note: The asterisk $* * *$ denote statistical significance at $1 \%$ level

\section{Discussion}

From the findings of the study, less than half (45.4\%) of the respondents were within the age group of 30-40 years and $64.3 \%$ of the respondents were males. This implied that respondents were in their active age, young and vibrant. Result also showed that males dominated the business of exportation of agricultural commodities. Nearly all $(95.4 \%)$ of the respondents had tertiary education. This indicated that farmers involved in exportation of agricultural commodities in Nigeria were educated. The mean years of farmers' experience of exportation of agricultural commodities was 5.84years. Findings further showed that a larger percentage (82\%) of respondents did not have access to credit facilities. According to Ayinde et al. (2015) study, who opined that agricultural credit guarantee scheme funds (ACGSF) was statistically beneficial to productivity and supply of export commodities. Also, from the findings, $47 \%$ of the respondents had been trained on production and export of exportable agricultural commodities. This illustrated that despite their tertiary education, they still sought for 
knowledge related to all activities involved in exportation of agricultural commodities. Furthermore, the study outcome showed that about $56 \%$ of the respondents' export cashew, $87.5 \%$ export ginger while $50 \%$ export cocoa respectively. Source of farmland used for cultivation by the respondents is majorly through lease. This signified that they can use the land for so many years. The mean selling price for cashew was $807,298.5782$ per tonnes, for ginger was $\$ 582,517.2414$ per tonnes and $\$ 959,012.8755$ per tonnes for cocol respectively. Almost half of the respondents stated that the major factor affecting their production output was market uncertainties. Based on the 4-point Likert scale used and the percentage results, it was discovered that the major agricultural trade policy actions that impacted export commodity productivity and supply volume of the respondents were Ancho Borrowers Programme in 2015 (2.848), followed by Unpeging of the Nigerian naira against the Dollar in 2016 (2.800), Duty free imports of agricultural equipment in 2012 (2.632), NIRSAL (Nigeria Incentive-Based Risk Sharing System for Agricultural Lending in 2013 (2.572) and Nigeria provides companies income tax holidays to pioneer status 2014 (2.518). This was in agreement with Akanni et al. (2005) and Ijirshar, (2015) who opined that policy had great impact on the value and level of exports of agricultural commodities. Similarly, studies of Ayinde et al. (2015) revealed that agricultural policies and agricultural credit guarantee scheme funds (ACGSF) were statistically important in export productivity as well as supply.

From the study, results revealed that unfavorable weather conditions $(64.3 \%)$, lack of government support and access to credit facilities (57.8\%), high transportation costs $(57.0 \%)$, high tariffs $(46.2 \%)$, price fluctuations $(43.0 \%)$ and unfavorable government policy $(35.9 \%)$ were very severe constraints encountered in the export of agricultural commodities. Moreover, poor access to information $(53.5 \%)$ was also a severe constraints identified by the exporters. The finding of this study was in line with APEDA who specified that transportation of products from one state to another is a huge challenge, followed by inadequate allocation of budget for capacity building and unavailability of certification and signing authority at the ports. This was in accordance with Cocoa Farmers Association of Nigeria (CFAN) who reported in 2018 that the challenges faced by their members include lack of government support, harsh weather situations/conditions and usage of counterfeit chemicals by the farmers. According to Ahmed and Sallam, (2018) who stated that before implementing some of the policies that can be used to boost the agricultural yields, it was significant to solve the challenges encountered by the farmers during exporting of their agricultural products. Similarly, Ejiogbu (2017) stated that the federal government of Nigeria in 2010/2011 restructured the agriculture sector via strategy implementation known as Agricultural Transformation Agenda (ATA) by means of setting up complementary programme interventions which was designed to unravel in an integrated and holistic manner the limitations as well as errors that have seized the development of agriculture sector for a long period of years (ATA, 2011). Age of respondents with a coefficient of -.053 and insignificant implied that there was a negative relationship between age and period when exporters supplied the highest volume of agricultural commodities. Level of education with a coefficient of 2.474 and significant denoted that there was a positive relationship with period when exporters supplied the highest volume of agricultural commodities. This simply means that increased in level of education would increase the period when exporters supplied the highest volume of agricultural commodities. Experience of exporters with a coefficient of -.194 showed a significant association with period when exporters supplied the highest volume of agricultural commodities. Source of farmland used for cultivation with a coefficient of .623 and significant relationship existed with period when exporters supplied the highest volume of agricultural commodities while source of seedlings with a coefficient of .404 showed a significant relationship with period when exporters supplied the highest volume of agricultural commodities.

\section{Conclusion and Recommendations}

The study concluded that Duty free imports of agricultural equipment, Ancho Borrowers Programme and NIRSAL (Nigeria Incentive-Based Risk Sharing System for Agricultural Lending were the agricultural trade policy that positively impacted export commodity productivity and supply volume. Furthermore, the major challenges faced by the exporters of agricultural commodities include unfavorable weather condition, lack of government support and access to credit facilities and high transportation costs. Findings indicated that educational level, experience of exporting, source of farmland used for cultivation and source of seedlings were significantly related with period when exporters supplied the highest volume of agricultural commodities. In reference to the findings, the following recommendations are stated:

i. Favorable agricultural policy that would encouraged farmers of agricultural commodities and exporters to consider exportation as a valuable venture should be introduced by the government.

ii. Government should provide financial support and access of credit facilities should be provided.

iii. Government should regularize stability of market price of agricultural commodities and this information should be shared among exporters.

\section{References}

Agricultural and Processed Food Products Export Development Authority (APEDA). Indian Agri Exports: Study 
on difficulties faced by the exporters in the supply chain of agriculture products.

Agricultural Transformation Agenda, (ATA), 2011. We will grow Nigeria's Agricultural sector. Federal of Ministry Agriculture and Rural Development Abuja, Nigeria. Draft for Discussion 9th September, 2011.

Ahmed, O. \& Sallam, W. 2018. Studying the volatility effect of agricultural exports on agriculture share of GDP: The case of Egypt. African Journal of Agricultural Research, 13(8), pp. 345-352.

Akanni, K. A., Adeokun, O. A. \& Akintola, J. O. 2005. Effects of trade liberalization policy on Nigerian Agricultural Exports. www.researcggate.net/publlication. Doi: 10.4314/jasr.v4i1.2803.

Akinbamowo, R. O. 2013. A review of government policy on agricultural mechanization in Nigeria. Journal of Agricultural Extension and Rural Development, 5(8), pp.146-153.

Al-Hazaimeh, A., K. Al-Hyari, \& M. Al-Nasour. 2011. Determinants of Aggregate Imports in Jordan: Empirical Evidence (1976-2008). Journal of Economic Development, Management, IT, Finance and Marketing 1(1): 18-38.

Assem A. H. \& Sebastian, H. 2013. Opportunities and constriants for small agricultural exporters in Egypt. International Food and Agribusiness Management Review, 16(4): 77-100.

Ayinde, O. E., Ilori, T. E., Babatunde, R. O. \& Ayinde, K. 2015. Impact of government agricultural policies on the major staple food prices in Nigeria (1966 - 2011). International Conference of Agricultural Economists, $28 \mathrm{pp}$.

Ayodele, O. 2009. Environmental considerations in Nigerian Agricultural Policies, Strategies and Programs. International Food Policy Research Institute (IFPRI), NSSP Report 4, 27pp.

Briggs, I. N. 2007. Nigeria: mainstreaming trade policy into national development strategies. African Trade Policy Centre (UN Economic Commission for Africa) Working paper No. 52, January 2007.

Central Bank of Nigeria, (CBN), 2010. Annual Report. www.cbn.gov.ng. 124pp.

Daramola, A., Ehi, S., Ukeje, E., \& Mclntire, J. 2007. Agricultural export potential in Nigeria. Economic Policy Options for a Prosperous Nigeria, Collier, P. and C. Pattillo (Eds). Palgrave Macmillan, London, 1-38

Dekle, R. \& H.R. Heajin. 2007. Exchange rate fluctuations, financing constraints, hedging, and exports: evidence from firm level data. Journal of International Financial Markets, Institutions and Money 17(2): 437-451.

Ekiran, J. O., Awe, I. T. \& Ogunjobi, J. O. 2014. Agricultural export and economic growth in Nigeria: A multivariate Johansen cointegration analysis. International Journal of Arts and Commerce, 3(3), pp. 89-98.

Ejiogu, A. O. 2017. Growth Enhancement Scheme (GES) of the Nigerian Agricultural Transformation Agenda: Looking back and thinking ahead. Nigeiran Agricultural Policy Research Journal (NAPReJ), 3(1): pp.2841.

Emenyonu C. A, Odii Marshall A. C. A, Onyemauwa C. S, \& Ulukwu O. C 2020. Effects of Fiscal Policy on the Exportation of Agricultural Products in Nigeria: A Vector Error Correction Model Approach. Universal Journal of Agricultural Research, 8(5), 146 - 157. DOI: 10.13189/ujar.2020.080502

Emerole, G. \& Edeoga, G. 2013. Empirical analysis of the problems and prospects of export marketing of nonoil agricultural product in Nigeria. European Journal of Business and Management, 5(23), pp. 96-102.

Gbaiye, O. G., Ogundipe, A., Osabuohien, E., Olugbire, O. O., Adeniran, O. A., Bolaji-Olutunji, K. A., Awodele, O. D., Aduradola 2013. Agricultural Exports and Economic Growth in Nigeria (1980 -2010). Journal of Economics and Sustainable Development, 4(16), pp. 1-5.

Gbetnkom, D. \& Khan, S.A. 2002. Determinants of agricultural exports: The case of Cameroon.AERC Research Paper 120, African Economic Research Consortium, Nairobi. 46pp.

Gujarati, D. N. \& Porter, D. C. 2009. "Basic Econometrics", 5th edition, New York: McGraw- Hill International

Haahti, A., V. Madupu, U. Yavas, \& E. Babakus. 2005. Cooperative strategy, knowledge intensity and export performance of small and medium sized enterprises. Journal of World Business, 40 (2): 124-138.

Ijirshar, V. U. 2015. The empirical analysis of agricultural exports and economic growth in Nigeria. Journal of Development and Agricultural Economics, 7(3), pp. 113-122.

Josling, T., Kym A., Andrew, S. \& Stefan, T. 2010. Understanding International Trade in Agricultural Products: One Hundred Years of Contributions by Agricultural Economists. American Journal of Agricultural Economics, 92(2): 424-446; doi: 10.1093/ajae/aaq011

Koksal, M. H. 2008. How export marketing research affects company export performance: evidence from Turkish companies. Marketing Intelligent \& planning Journal 26(4): 416-430.

Laborde, D. \& Martin, W. 2012. Agricultural trade: what matters in the Doha round? Annual Review of Resource Economics, 4: 265-283.

Mesike, C. S. 2012. Impact of Government Agricultural Policies on Exports of Cocoa and Rubber in Nigeria. Agricultura Tropica Et Subtropica 2012:45(4).

Morgan, R.E. 1997. Export stimuli and export barriers: evidence from empirical research studies. European Business Review 97(2): 68-79.

Ngirente, E. 2008. Les marchés agricoles intérieurs et les mutations agro-économiques en milieu rural rwandais, application à la filière de la pomme de terre, Thèse de doctorat, UCL. 
Nwabunike, M. O. 2015. Constraints of fish marketing in Abakaliki Metropolis. International Journal of Fisheries and Aquatic Studies, 2(4), pp. 337-344.

Okpara, J.O. \& N. Kumbiadis. 2008. SMEs export orientation and performance: evidence from a developing economy. International Review of Business Research Papers 4(1): 109-119.

Osabuohien, E., Obiekwe, E., Urhie, E. \& Osabohien, R. 2018. The inflation rate, exchange rate volatility and exchange rate pass-through nexus: The Nigerian experience, Journal of Applied Economics Sciences, Volume XIII, Spring, 2(56): 574-585.

Plecher, H. 2020. Distribution of gross domestic product (GDP) across economic sectors Nigeria 2019. Statista.com/statistics/3823.

Sousa, C. M., F. J. Martinez-Lopez \& F. Coelho. 2008. The determinants of export performance: a review of the research in the literature between 1998 and 2005. International Journal of Management Review 10(4): 343374.

Tesfom, G. \& C. Lutz. 2006. A Classification of export marketing problems of small and medium sized manufacturing firms in developing countries. International Journal of Emerging Markets 1(3): $262-281$.

Verter, N. 2015. The application of international trade theories to agriculture. Mediterranean Journal of Social Sciences, 6(6): 209-219.

Verter, N. \& Bečvařova, V. 2014. Analysis of some drivers of cocoa export in Nigeria in the era of trade liberalization. Agris On-Line Papers in Economics and Informatics, 6(4): 208-218.

Verter, N. \& Bečvařova, V. 2016. The Impact of Agricultural Exports on Economic Growth in Nigeria. Acta Universitatis Agriculturae et Silviculturae Mendelianae Brunensis, 64(2): 691-700. 